\title{
Countermeasures and Interpretation: Operation for Vocational Schools Based on Marketing Perspective
}

\author{
Yang Zhaohui Dong Zhaowei \\ Institute of Higher Vocational Education, \\ Hebei College of Industry and Technology, \\ Shijiazhuang 050091, China \\ yangzhaohui2006@yahoo.com.cn
}

\begin{abstract}
With market economy deepening, Educational system oriented by consumers is replaced by producers. It is showed that education goes into operating times. Market could affect social industries by competition mechanism, supply and support mechanism and price mechanism. How to establish service oriented by market, use successful experience for reference, place them into market, and understand clients and how to know the future. For that purpose, vocational schools under changing sharply environment should realize resource allocation for the best by changing idea toward role in management. All done are to ensure education in a healthy and sustainable development.
\end{abstract}

Keywords: market school peration service development

\section{Introduction}

The environment is changing sharply in the $21 \mathrm{st}$ century. Seeking hi-tech and economic globalization makes education go to the forward position. Educational market in China has become one part of world educational markets under the influence of internationalization. With the mature process of socialist market econ- omy, market could affect social industries by competition mechanism, supply and support mechanism and price mechanism. As a social phenomenon, education is inevitably affected by market. Educational system oriented by consumers is replaced by producers. It is showed that education goes into operation times.

Facing complicated surroundings, some schools with outdated management meet the troubles of low efficiency, poor student pool and wrong specialty arrangement. They could hardly live. On the contrary, some schools can deal with the changing conditions. "This is mainly attributed to strategy on the basis of educational market and idea of market oriented service. Lessons of business are used for reference by those schools, policies are implemented, and new ways are adopted to increase their ability of existence and development." Leaders in the vocational schools are guided by market consciousness. They should think highly of cost of organization and make use of tangible and invisible resources to keep it healthy and sustainable development.

\section{Be in the market, transfer idea}

With a speed of national industrialization, it is not enough that one vocational school maintain only good student pool. All schools are being challenged by fu- 
ture education effectiveness. So do those schools which keep close touch with economy. Coping with more and more complicated environment, satisfying their students, industries, society, variety and characteristics, schools should develop vocational education with distinguish feature and broad influence. They must put themselves into the market both local education and regional economy in positive attitude. And they should introduce their features, values and service to indirect or direct clients such as students, parents, communities, industries and so. Mixing their strategies and features into surroundings skillfully, schools could make mass identify them from varied ones, catch agreement and support.

Nowadays, market has become the main mode of resource allocation, although there are some different sounds. There is a words said by Philip. Kotler, a worldwide marketing master, "marketing is a common social society" ${ }^{11]}$. The advantage of one school cannot produce benefit. Schools integrate their effective strategic operation and advantage may be increased in value. As managers, presidents try their best to find effective ways to get resource what they want. They must be action on the following aspects: idea of operation, analysis of market and service designing. With effective communication and evaluation, presidents make multistakeholder ratify their ideas and service, recognize features of schools in the process of interacting with staffs, students, parents, industries and governments. Only if those stakeholders are anxious for service from schools, the advantages of schools will increase in value.

In the traditional idea of school operation, the duty of presidents is how to realize educational objective, pay more attention to plan, organize, lead and control educational activities. However, under the economic market, vocational schools want to get more merit resource, the governors of schools must start out from their true features, aim at improving benefit and efficiency, try their best to realize good allocation and reconstruction of resource. Presidents face new requirements in the operation of schools: pay attention to quality and satisfactory in order to social and economic benefits, guarantee sustainable development; implement open policy, concern inside and outside affairs, place schools properly according to economic law and educational law, characteristics; presidents must start out from service, competition and existence and seek subtle measures; change traditional thinking which is up to government, be responsible for teaching staffs, students and parents; satisfy them.

From the actual meaning of school operation point of view, if vocational schools separate from society, educational quality and condition wouldn't have adapted the development of society, resulted in simple educational objective, outmoded teaching content, inflexible educational pattern, low efficiency and limited development space.

Vocational schools transfer ideas under the operation school as follows:

Concern needs of clients when they design educational service. Philip. Kotler pointed out in his book "strategic marketing for educational institutes": "Oriented by marketing, educational institute would concentrate its energy in satisfy clients." At the meantime, he referred: "satisfactory of clients do not mean that educational institute provides 'hot' production instead of concerning its mission and core competition. It should seek those who were interested in its service and production, then make them attractively." Therefore, vocational schools should not only remember their missions but also design varied program of educational service for satisfying needs of students, industries and society. For instance, students in the schools are provided with opportunities 
of autonomous study and practical activities; industries are provided with pertinent job training service, aided to develop training resources for promoting autonomous training capability; industries are helped to establish elastic learning rules and learning point cards regulations and those schools provide service on site.

In the mode of traditional management, specialty arrangements of vocational schools embody promotion logic of production concept. Some lacks market investigation and analysis, objectives and standards can not fit with social requirements. Everything is nice in one's own garden. Schools are devoted to improve quality of specialty and perfect subject, ignore modulation of industrial structure in the development of economy, and result in lacking coupling between specialties and industries. Specialty is a linkage both vocational schools and social economy. Without social needs, whatever specialties may be good, educational resources are wasted. School would be knocked out. So specialty arrangement should adopt the means of promotion concept. Schools should establish marketing investigation to couple specialty and industry, learning and job, skills and job requirements, learning circumstances and manufacture surroundings, individual virtue and career quality. Students with knowledge and technology could meets the requirements both industries and individuals. It is necessary to match between specialty arrangements and marketing needs.

Under the idea of school operation, vocational schools are suggested to pay attention to students for overall development. They should not only concern their students whose scores and employment rates, but also concern whether the students have learned necessary knowledge and skills or not, whether they have necessary quality and ability or not, whether they have established foundation for realizing individual values and creating social values or not. That is to say, vocational schools should change employment oriented to employment ability oriented, stress to improve practice ability, creation ability, employment ability and pioneering ability. Vocation not only affects education but also education affects vocation. Thus vocational education may unite its vocational, productive and social nature.

In the process of concerning students, there is a problem which should be solved. It is school-school barrier. Such as, students may transfer to other schools by curriculum agreements and universities union.

\section{Know client, win market}

In his book "Strategic Marketing for Schools", Brent Davies pointed out: "marketing for school is an activity which school should positively introduce its target, value, service and product into students, parents, staffs and more broadly community." ${ }^{[2]}$ Students in vocational school are not only to accept its products and consume its service directly, but also decide whether they would choose a school or not. They are key role. Relative to industries benefit from school works with direct or indirect mode, and therefore are school's clients and objects for marketing. There is an important premise for school marketing which requests all staffs of school to understand its target and value, consider the features of its direct or indirect clients. So the school could provide different service according to different client groups. That is to say, successful school manager could effectively develop worthy educational service. It is necessary to point out that common business affairs do not concern their consumers who are qualified or not. However, it is different for common business that educational service is evaluated though its good quality or bad quality in cultivat- 
ing students. For instance, they concern whether students have learned the knowledge and technology or not, whether students have grasped relative working skills, whether students have gained diplomas or certifications or not. Because of bilateral activity between teaching and learning, high or low educational quality not only depends on its teaching capacity, but also depends on studying capability in students themselves as well as participating in it. Students needs in vocational schools look forward to enhancing their studying capability apart from hoping to gain the knowledge and technology for the future employment. The employers expect employees with studying capability to flesh the enterprises out, strengthen its further development. So whether the students, parents and industries accept a school or not, it will involve in the instructional conditions of school and involve in the capability for arousing studying motive and the level for improving studying capability.

Otherwise, what kind of school should be chosen are student's autonomous rights, but the students have no money for paying tuition so that their parents are the true purchasers in educational products or service. It is general to say, the parents are prior to choose a road witch can make their children to reach higher class. That is easier to understand why they choose universities not choose higher vocational colleges. Then the presidents in those colleges must pay attention to parents' decisions, establish effective communication institution. To win support both students and their parents, meanwhile win potential clients by proper channels. It is important to do that. Because of choosing one vocational school, a student may not like it more than others, but often is fa- miliar with it. Or he chooses this school because his classmates, friends or others are there. They are back to school for search a feeling of warm and fragrant or a feeling of ever experience. They have a feeling of glory. It happens often that older brother sent his young brother or neighbor's brother to same school which he had studied in it. Like that, vocational schools establish effective communication institution with those schools where students are from to choose potential clients including graduated students introduction. It is worth to notice that employment rate and quality of vocational schools could affect potential students. If students graduated from school are often employed by good companies, it will not worry about its students' source.

In fact, many factors in the market will affect vocational school. Provided effective communication is essential core of running for vocational school, schools which have sufficient recognition about the feature of aimed clients and make good strategy for running can win the market.

( This Paper is A Part of Research Achievement of Project Supported by National Office of Education Science Planning, Approval No.DDA110202.)

\section{References}

[1] Philip. Kotler. "The principles of marketing," Pearson Educatio,pp.55.

[2] Brent Davies. "Strategic marketing for schools : how to harmonise marketing and strategic development for an effective school," London : Pitman, pp.33,1997. 